\title{
Delving into the environmental aspect of a Sardinian white wine: From partial to total life cycle assessment
}

\author{
Alessandra Fusi ${ }^{a}$, Riccardo Guidetti ${ }^{a}$, Graziella Benedetto ${ }^{\text {b,* }}$ \\ a Dipartimento di Scienze Agrarie Ambientali, Produzione, Territorio, Agroenergia, University of Milano Italy, Via Celoria 2, 20133 Milano, Italy \\ b Department of Science for Nature and Environmental Resources, University of Sassari, Via Piandanna, 07100 Sassari, Italy
}

\section{H I G H L I G H T S}

- A 'cradle to grave' E-LCA was used for $750 \mathrm{ml}$ bottle of a Sardinian white wine.

- The phases of vine planting, distribution and final disposal are included in the LCA.

- Hot-spots are glass bottle production and vine planting due to diesel consumption.

- The impact categories more affected by transport were AP, EP, POCP and GWP.

- Improvements were a lighter glass bottle or the use of polylaminate container.

\section{A R T I C L E I N F O}

\section{Article history:}

Received 8 September 2013

Received in revised form 29 November 2013

Accepted 30 November 2013

Available online $\mathrm{xxxx}$

\section{Keywords:}

Life cycle assessment

Winemaking

'Cradle to grave'

Sardinia

\begin{abstract}
A B S T R A C T
The aim of this study was to deepen the assessment of the environmental impacts of a white wine produced in Sardinia (FU $750 \mathrm{ml}$ ), performing an attributional LCA. The system boundaries were extended, from 'cradle to gate' (partial LCA) of a previous study, to 'cradle to grave' (total LCA), in order to identify the environmental impacts occurring along the wine life cycle stages (vine planting, grape production, wine production, bottling and packaging, distribution, final disposal of the glass bottle).

Some assumptions were made in order to quantify the environmental impact of the transportation phase, regarding the few data which were available.

Inventory data were mainly collected through direct communication with the Company involved in the study. Results showed that the environmental performance of wine was mostly determined by the glass bottle production (for all impact categories except ozone layer depletion). The second contributor was the agricultural phase, which included two sub-phases: vine planting and grape production. Results showed that the vine planting subphase was not negligible given its contribution to the agricultural phase, mainly due to diesel fuel consumption. Transportation impact was found to be relevant for long distance distribution (USA); the impact categories more affected by transport were acidification, eutrophication, photochemical oxidation and global warming potential. Suggested opportunities to reduce the overall environmental impact were the introduction of a lighter glass bottle or the substitution of the glass bottle with a polylaminate container.
\end{abstract}

(C) 2013 Elsevier B.V. All rights reserved.

\section{Introduction}

Over the past two decades, the worldwide awareness regarding environmental issues has consistently increased: consumers are now changing their behaviour to integrate environmental considerations into lifestyle choices. The environmental aspect is now one of the variables taken into consideration by consumers during the purchasing process. In some cases, consumers are willing to pay a premium for environmentally friendly products (Barber et al., 2009). As mentioned

\footnotetext{
* Corresponding author. Tel.: + 39079 229355, + 393317351805 (mobile); fax: + 39079229356

E-mail addresses: alessandra.fusi@unimi.it (A. Fusi), riccardo.guidetti@unimi.it (R. Guidetti), gbenedet@uniss.it (G. Benedetto).
}

by Berners-Lee et al.'s (2011) businesses of all sizes are increasingly looking to modify their actions to manage their impact, to protect their reputations and to prepare for tighter regulations. Over the last few years, the evaluation and communication of products with environmental impacts, by means of an eco-label, are starting to gain ground within the agro-food sector. The farm-gate approach has the advantage of encouraging the use of best practices in each production stage, allowing, on the one hand, the reduction of emissions which are directly controlled by the farmer and, on the other hand, the creation of policies that are applicable at the company level (Dick et al., 2008). The agricultural sector is considered, after fossil fuels, the main cause of greenhouse gas emissions. According to the last published IPCC report, the agricultural sector is the second responsible for global GHG production, emitting between 5.1 and $6.2 \mathrm{Gt} \mathrm{CO}_{2}$ eq., which corresponds to the $10-$ 
$12 \%$ of total anthropogenic GHG emissions and, including forestry activities, and is responsible for $50 \%$ and $70 \%$ of methane $\left(\mathrm{CH}_{4}\right)$ and nitrous oxide $\left(\mathrm{N}_{2} \mathrm{O}\right)$ emissions, respectively, and for $25 \%$ of the carbon dioxide production $\left(\mathrm{CO}_{2}\right)$ (Smith et al., 2007).

This is due to direct emissions deriving from agricultural operations, for example carbon dioxide $\left(\mathrm{CO}_{2}\right)$ emissions from the use of diesel by tractors and irrigation equipment or emissions from agricultural inputs used (e.g. fertiliser, herbicides and pesticides).

However, it is important to consider indirect emissions generated off-farm as a result of the manufacturing of inputs used on the farm, for example GHG emissions from the use of natural gas in the production of commercial fertiliser and chemicals. As stated by Coderoni and Bonati (2013), the agricultural sector will represent one third of European emissions by 2050 (if decarbonisation of other sectors has not yet occurred). Therefore, the relevance of the agricultural sector in climatic policy is expected to increase.

The wine sector must deal with this scenario, and emissions associated with both the productive phase and the distribution phase must be considered. With regard to the latter, it must be highlighted that wine largely contributes to the global agro-food trade: in 2011, 10 million $t$ of wine were exported all over the world and wine is the 19th highest agro-food product exported by quantity and the 7th by value (1000\$) (FAOSTAT).

The whole supply chain must therefore be considered in order to take into account all impacts deriving from wine production, as suggested for other agro-food sectors (Iribarren et al., 2010; Berners-Lee et al., 2011).

Protocols for the evaluation of wine emissions are currently being set up by important Institutions, like the International Organisation of Vine and Wine (OIV). ${ }^{1}$ Therefore, the whole industry must address this issue in the very near future, private companies included.

Italy is one of the leading wine producing countries, with more than 42 million hl produced in 2011 (OIV (International Organisation of Vine and Wine), 2013), and plays a dominant role among the traditional exporting countries, according to FAO data (2011), accounting for $23 \%$ of global wine exports. The UK, the United States and Germany are its main buyers (Istat-Coeweb, 2010).

Nowadays, we are witnessing the rise of a "green competition" in the international wine trade. Environmental issues are in fact not only popular both in traditional wine importing countries (e.g. the United Kingdom) and in global larger markets (e.g. the United States), but also in countries that have been recently gaining a share of the export market (e.g. Australia, New Zealand and South Africa) and in traditionally net exporting countries (e.g. France).

Hence, there is interest in analysis that assesses the environmental impacts linked to the production of an Italian bottle of wine that is widely sold in markets where the interest on environmental issues is growing and other competitors are embracing environmental management systems (as Hardie (2000) pointed out, Australian wine producers).

In this context, it is important to be able to assess the environmental load linked to wine production. As mentioned by Zamagni et al. (2012), the European Commission states that "LCAs provide the best framework for assessing the potential environmental impacts of products currently available" (CEC, 2003). LCAs might be conducted by an industry sector in order to identify areas where improvements can be made, in environmental terms. In recent years, a number of major companies have cited LCAs in their marketing and advertising, to support claims that their products are 'environmentally friendly' ${ }^{2}$ or even 'environmentally superior' to those of their rivals (World Resource Foundation).

\footnotetext{
${ }^{1}$ Pattara et al. (2012b) used the OIV guidelines as a methodological basis in their cradle to gate study.

${ }^{2}$ Examples are Soave Consortium in Italy and Taylors Wines in South Australia (Lambert, 2010).
}

Life cycle assessment (LCA) is a standardised methodology used for estimating the environmental burdens associated with the life cycle of products or processes (ISO, 2006a,b). This methodology is considered to be effective for evaluating environmental performance in the food and beverage sector (Andersson, 1998; Cerutti et al., 2011; GonzálezGarcía et al., 2013a,b), and, of course, in the viticulture and vinification sectors. Several studies have been carried out in order to assess the environmental performance of wine using the life cycle assessment approach (e.g. Zabalza et al., 2003; Notarnicola et al., 2003; Aranda et al., 2005; Montedonico, 2005; Gonzalez et al., 2006; Ardente et al., 2006; Petti et al., 2006; Rugani et al., 2009; Carta, 2009; Colman and Päster, 2009; Schlich, 2010; Petti et al., 2010; Gazulla et al., 2010; Barry, 2011; Bosco et al., 2011; Pattara et al., 2012a; Point et al., 2012; Vázquez-Rowe et al., 2012; Comandaru et al., 2012; Neto et al., 2013; Vázquez-Rowe et al., 2013; Benedetto, 2013; Villanueva-Rey et al., 2013).

As can be seen from Rugani et al. (2013), some of them adopted a 'cradle to grave' perspective, with the inclusion of the distribution phase (e.g. Gazulla et al., 2009; Point et al., 2012; Neto et al., 2013), while others preferred a 'cradle to gate' approach, without taking into consideration the distribution (e.g. Vázquez-Rowe et al., 2012; Benedetto, 2013). With some exceptions (Montedonico, 2005; Pizzigallo et al., 2008; Rugani et al., 2009; Carta, 2009; Bosco et al., 2011; Comandaru et al., 2012; Benedetto, 2013), the vine planting phase represents a stage of the wine life cycle that is rarely considered in wine LCA studies due to a lack of data.

According to these studies, the production of glass bottles and the viticulture phase are environmentally relevant in the overall wine life cycle.

Over the years, more and more importance has been given to the assessment of the life cycle as a whole: therefore, the interest has shifted from partial $^{3}$ to total ${ }^{4}$ LCA, as already outlined on another occasion (Benedetto et al., 2013). For this reason, this study proposes the evaluation of environmental impacts associated with the production of a white wine produced in Sardinia by Sella \& Mosca, including additional stages of the production process compared to a previous study (Benedetto, 2013).

The aim of this study was to deepen the assessment of the environmental impacts of a white wine produced in Sardinia (FU $750 \mathrm{ml}$ ), performing an attributional LCA. The system boundaries were extended from 'cradle to gate' (partial LCA) to 'cradle to grave' (total LCA), in order to identify the environmental impacts occurring along the wine life cycle stages (vine planting, grape production, wine production, bottling and packaging, distribution, final disposal of the glass bottle). The analysis was performed on Vermentino wine produced by one of the biggest companies in Europe (Sella \& Mosca), which exports its wine all over the world, won the award for the Eco-friendly winery in 2012 and was named winery of the year in 2013 in the Gambero Rosso Guide. This company, founded more than one century ago, has more than 550 ha of vineyard and produces approximately 7 million bottles per year; the production of Vermentino "La Cala", which was selected for this study because it represents a flagship product of the company's portfolio, amounts to 500,000 bottles per year.

\footnotetext{
3 The PEF Guide (2012) specifies that 'cradle to gate' is "a partial product supply chain, from the extraction of raw materials (cradle) up to the manufacturer's "gate". The distribution, storage, use stage and end-of-life stages of the supply chain are omitted" (p. 75); the 'gate to gate' and 'gate to grave' LCAs are also partial (p. 76). The same definition is included in the ENVIFOOD Protocol Environmental Assessment of Food and Drink Protocol (2012, p. 13).

4 'Cradle to grave' LCA is referred to: "a product's life cycle that includes raw material extraction, processing, distribution, storage, use, and disposal or recycling stages. All relevant inputs and outputs are considered for all of the stages of the life cycle" (PEF Guide, p. 75); in the ENVIFOOD Protocol, this definition is reported for the cradle to grave inventory as "a complete life cycle of a product which includes all the consecutive and interlinked stages of a product system from material acquisition through to end-of-life" (p. 13).
} 


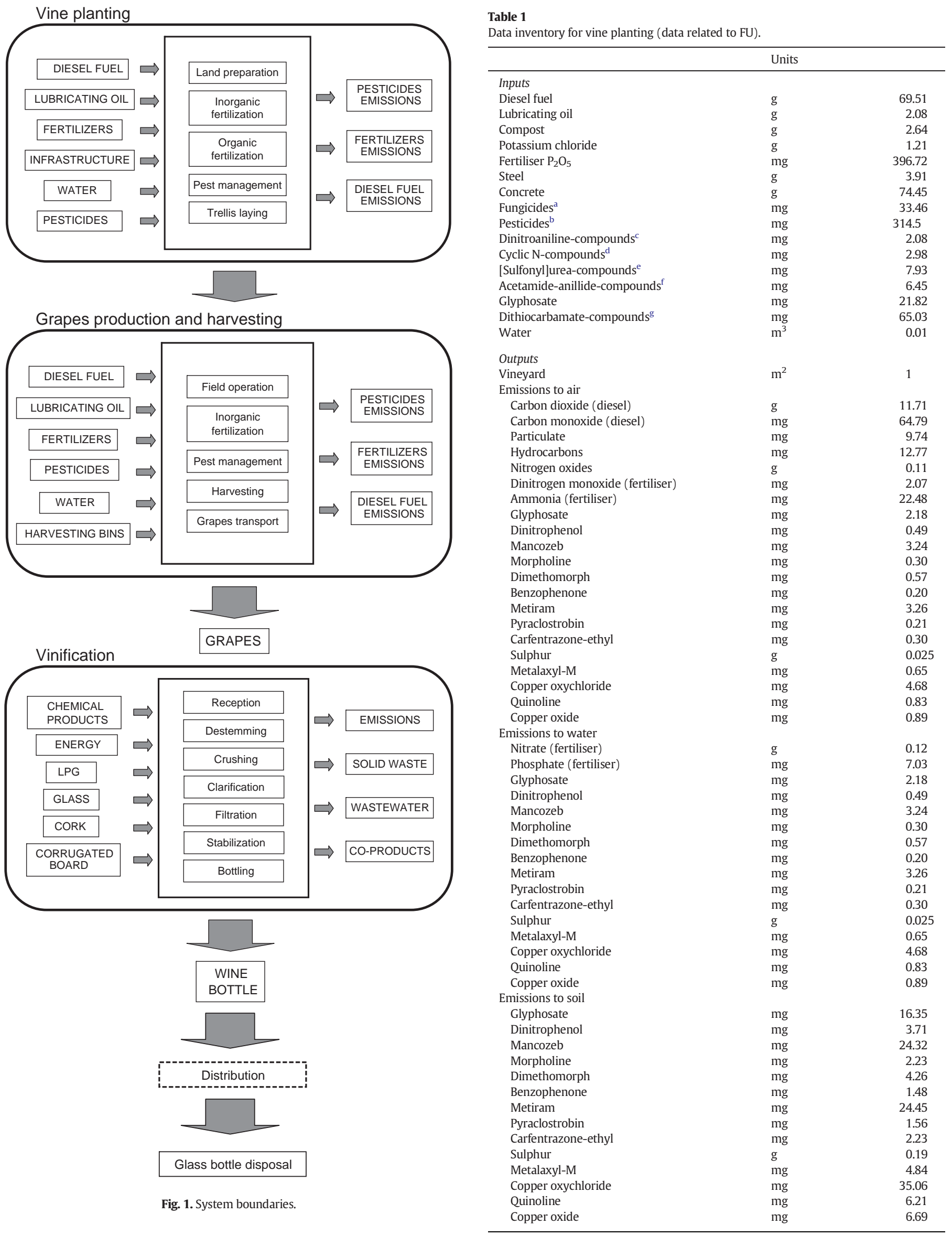




\section{Material and methods}

\subsection{Goal and scope definition}

The environmental performances of a Sardinian wine (Vermentino) were assessed using the LCA methodology.

The selected functional unit (FU) was a bottle $(750 \mathrm{ml})$ of Vermentino white wine produced by a large company, Sella \& Mosca.

The studied system (Fig. 1) was not restricted to the wine making process but also included the agricultural phases of vine planting and grape production, as well the final disposal of packaging (glass bottle).

The present study was carried out at two levels:

1 Level A ignored the wine transportation phase;

2 Level B included the wine transportation phase.

\subsection{Inventory}

Data concerning field operations and the wine making process were directly obtained from the company involved in the analysis. Foreground data were integrated with database information (Ecoinvent version 2.2 (Frischknecht et al., 2007); LCA Food DK (Nielsen et al., 2003)).

Data concerning grape production and wine making processes refer to 2012, which can be considered an average year since grape production has remained approximately constant over the last 5 years.

\subsubsection{LCI of agricultural phase}

The vine planting phase lasts for approximately three years, after which the vineyard starts being productive. A vineyard is considered to be productive for 27 years (information provided by the company), and vines at the end of their lifetime are used to produce energy. The analysis carried out did not take into account the end of life of the vineyard.

Table 1 reports a data inventory for the vine planting phase; Table 2 shows a data inventory for the grape production phase.

For the agricultural phase (both for vine planting and grape production), the emissions due to fertiliser were included: nitrogen emissions to air and water (dinitrogen monoxide (direct and indirect emissions), ammonia and nitrate) were computed using the IPCC (2006a,b) (a) emission factors; phosphate emissions were calculated in accordance with Smil (2000). Since grape stalk is spread onto the field as a fertiliser, the emissions due to its use were also computed. The nitrogen content in grape stalk was calculated in accordance with Rossini et al. (2010).

In order to calculate pesticide emissions precisely, it is necessary to have data regarding, among others, the way in which a pesticide is applied and the meteorological conditions during application (EMEP/ EEA, 2013). Since all of these data were not available, the emission factors used can be considered as first estimates. Pesticide emissions into the air, water and soil were estimated in accordance with Margni et al. (2002) and Audsley (1997). According to these studies, the fraction of active ingredient entering the soil is assumed to be $85 \%$ of the total applied quantity; $5 \%$ remains on the plant and $10 \%$ is emitted into the air. The run-off of the active ingredient from the soil into the water is assumed to be a maximum of $10 \%$ of the applied dose. Regarding fuel use, the emissions that each machine generates for field operations

\footnotetext{
Notes to Table 1:

a Meptyldinocap, spiroxamina, dimethomorph, metrafenone, quinoxifen, spirotetramat 48.

b Sulphur, copper oxychloride, copper hydroxide.

c Pyraclostrobin.

d Carfentazone-etile.

e Flufenoxuron.

f Metalaxil M.

g Mancozeb, metiram.
}

Table 2

Data inventory for grape production (data related to FU).

\begin{tabular}{|c|c|c|}
\hline & Units & \\
\hline \multicolumn{3}{|l|}{ Inputs } \\
\hline Diesel fuel & $\mathrm{g}$ & 12.1 \\
\hline Lubricating oil & $\mathrm{g}$ & 0.36 \\
\hline Fertiliser (N) & $\mathrm{mg}$ & 13.5 \\
\hline Fertiliser $\left(\mathrm{P}_{2} \mathrm{O}_{5}\right)$ & $\mathrm{mg}$ & 83 \\
\hline Fertiliser $\left(\mathrm{K}_{2} \mathrm{O}\right)$ & $\mathrm{g}$ & 0.11 \\
\hline Fungicides $^{\mathrm{a}}$ & $\mathrm{g}$ & 0.34 \\
\hline Pesticides ${ }^{\mathrm{b}}$ & $\mathrm{g}$ & 3.17 \\
\hline Dinitroaniline-compounds ${ }^{c}$ & $\mathrm{mg}$ & 21 \\
\hline Cyclic N-compounds ${ }^{\mathrm{d}}$ & $\mathrm{mg}$ & 30 \\
\hline [Sulfonyl]urea-compounds ${ }^{\mathrm{e}}$ & $\mathrm{mg}$ & 80 \\
\hline Acetamide-anillide-compounds ${ }^{\mathrm{f}}$ & & 65 \\
\hline Glyphosate & $\mathrm{g}$ & 0.22 \\
\hline Dithiocarbamate-compounds ${ }^{g}$ & $\mathrm{~g}$ & 0.66 \\
\hline HDPE (bins) & $\mathrm{mg}$ & 46.28 \\
\hline Water & $\mathrm{m}^{3}$ & 0.10 \\
\hline Land & $\mathrm{m}^{2}$ & 1 \\
\hline \multicolumn{3}{|l|}{ Outputs } \\
\hline \multicolumn{3}{|l|}{ Product } \\
\hline Grapes & $\mathrm{kg}$ & 1.071 \\
\hline \multicolumn{3}{|l|}{ Emissions to air } \\
\hline Carbon dioxide (diesel) & $\mathrm{g}$ & 38 \\
\hline Carbon monoxide (diesel) & $\mathrm{g}$ & 0.26 \\
\hline Particulate & $\mathrm{mg}$ & 40 \\
\hline Hydrocarbons & $\mathrm{mg}$ & 50 \\
\hline Nitrogen oxides & $\mathrm{g}$ & 0.38 \\
\hline Dinitrogen monoxide (fertiliser) ${ }^{\mathrm{h}}$ & $\mathrm{mg}$ & 8.09 \\
\hline Ammonia (fertiliser) ${ }^{\mathrm{h}}$ & $\mathrm{mg}$ & 90 \\
\hline Glyphosate & $\mathrm{mg}$ & 23 \\
\hline Dinitrophenol & $\mathrm{mg}$ & 5 \\
\hline Mancozeb & $\mathrm{mg}$ & 32.5 \\
\hline Morpholine & $\mathrm{mg}$ & 3 \\
\hline Dimethomorph & $\mathrm{mg}$ & 5.75 \\
\hline Benzophenone & $\mathrm{mg}$ & 2 \\
\hline Metiram & $\mathrm{mg}$ & 33 \\
\hline Pyraclostrobin & $\mathrm{mg}$ & 2 \\
\hline Carfentrazone-ethyl & $\mathrm{mg}$ & 3 \\
\hline Sulphur & $\mathrm{g}$ & 0.26 \\
\hline Metalaxyl-M & $\mathrm{mg}$ & 6.5 \\
\hline Copper oxychloride & $\mathrm{mg}$ & 30 \\
\hline Quinoline & $\mathrm{mg}$ & 4 \\
\hline Copper oxide & $\mathrm{mg}$ & 9 \\
\hline \multicolumn{3}{|l|}{ Emissions to water } \\
\hline Nitrate (fertiliser) ${ }^{\mathrm{h}}$ & $\mathrm{g}$ & 0.48 \\
\hline Phosphate (fertiliser) & $\mathrm{mg}$ & 1 \\
\hline Glyphosate & $\mathrm{mg}$ & 23 \\
\hline Dinitrophenol & $\mathrm{mg}$ & 5 \\
\hline Mancozeb & $\mathrm{mg}$ & 32.5 \\
\hline Morpholine & $\mathrm{mg}$ & 3 \\
\hline Dimethomorph & $\mathrm{mg}$ & 5.75 \\
\hline Benzophenone & $\mathrm{mg}$ & 2 \\
\hline Metiram & $\mathrm{mg}$ & 33 \\
\hline Pyraclostrobin & $\mathrm{mg}$ & 2 \\
\hline Carfentrazone-ethyl & $\mathrm{mg}$ & 3 \\
\hline Sulphur & $\mathrm{g}$ & 0.26 \\
\hline Metalaxyl-M & $\mathrm{mg}$ & 6.5 \\
\hline Copper oxychloride & $\mathrm{mg}$ & 30 \\
\hline Quinoline & $\mathrm{mg}$ & 4 \\
\hline Copper oxide & $\mathrm{mg}$ & 9 \\
\hline \multicolumn{3}{|l|}{ Emissions to soil } \\
\hline Glyphosate & $\mathrm{g}$ & 0.17 \\
\hline Dinitrophenol & $\mathrm{mg}$ & 37.5 \\
\hline Mancozeb & $\mathrm{g}$ & 0.24 \\
\hline Morpholine & $\mathrm{mg}$ & 22.5 \\
\hline Dimethomorph & $\mathrm{g}$ & 43.13 \\
\hline Benzophenone & $\mathrm{mg}$ & 15 \\
\hline Metiram & $\mathrm{g}$ & 0.24 \\
\hline Pyraclostrobin & $\mathrm{mg}$ & 15 \\
\hline Carfentrazone-ethyl & $\mathrm{mg}$ & 22.5 \\
\hline Sulphur & $\mathrm{g}$ & 1.95 \\
\hline Metalaxyl-M & $\mathrm{mg}$ & 48.75 \\
\hline Copper oxychloride & $\mathrm{g}$ & 0.23 \\
\hline Quinoline & $\mathrm{mg}$ & 30 \\
\hline Copper oxide & $\mathrm{mg}$ & 67.5 \\
\hline
\end{tabular}


Table 3

Data inventory for wine making (data related to FU).

\begin{tabular}{llc}
\hline & Units & \\
\hline Inputs & & \\
Harvested grapes & $\mathrm{kg}$ & 1.071 \\
Liquid sulphur dioxide & $\mathrm{mg}$ & 64.3 \\
Liquid nitrogen & $\mathrm{g}$ & 0.37 \\
Bentonite & $\mathrm{g}$ & 0.35 \\
LPG & $\mathrm{g}$ & 0.64 \\
Water (tap) & $\mathrm{kg}$ & 5.34 \\
Electricity & $\mathrm{MJ}$ & 0.4 \\
Outputs & & \\
Products & & \\
$\quad$ Wine & $\mathrm{l}$ & 0.75 \\
Marc and lees & $\mathrm{kg}$ & 0.27 \\
Stalks & $\mathrm{kg}$ & 0.05 \\
Emissions & & \\
$\quad$ Ethanol (fermentation) & $\mathrm{g}$ & 0.165 \\
Carbon dioxide (LPG) & $\mathrm{g}$ & 1.87 \\
Dinitrogen monoxide (LPG) & $\mathrm{mg}$ & 0.003 \\
$\quad$ Methane (LPG) & $\mathrm{mg}$ & 0.03 \\
Waste & & \\
$\quad$ Wastewater & $\mathrm{kg}$ & 5.34 \\
\hline
\end{tabular}

were estimated using data from the Swiss Federal Office for the Environment (DETEC (Federal Department of the Environment, Transport, Energy and Communications)).

No change in the overall soil carbon content was assumed because the fields were previously dedicated to vine cultivation.

\subsubsection{LCI of wine making phase}

Carbon sequestration by grape vines and the subsequent release of $\mathrm{CO}_{2}$ during fermentation were excluded from the analysis (Notarnicola et al., 2003; Carta, 2009; Benedetto, 2013; Rugani et al., 2013). Moreover the PEF Guide reports that "credits associated with temporary (carbon) storage or delayed emissions shall not be considered in the calculation of the default EF impact categories" (p. 36). On the other hand, emissions of ethanol were included as they are known to contribute to photochemical oxidation (Notarnicola et al., 2003; Pizzigallo et al., 2008; VázquezRowe et al., 2012; Point et al., 2012; Neto et al., 2013). Ethanol emissions were estimated using the United States Environmental Protection Agency (USEPA) (1995) emission factor.

Air emissions associated with liquefied petroleum gas (LPG) use were estimated using emission factors from IPCC (2006b).

Table 3 reports a data inventory for the wine making phase.

\subsubsection{LCI for the bottling and packaging phase}

Since this phase takes place within the winery, it was not possible to acquire specific data regarding electricity use for the bottling and packaging subsystem. Therefore, the entire electricity consumption was assigned to the wine making stage based on the assumption that only a small proportion of the total energy is attributable to bottling and packaging (Guidetti, 2005; Bosco et al., 2011).

The same considerations were made for water use. Table 4 reports the inventory of the bottling and packaging phase.

\footnotetext{
Notes to Table 2:

a Meptyldinocap, spiroxamina, dimethomorph, metrafenone, quinoxifen, spirotetramat 48.

b Sulphur, copper oxychloride, copper hydroxide.

c Pyraclostrobin.

d Carfentazone-etile.

e Flufenoxuron

f Metalaxil M.

g Mancozeb, metiram.

h Emissions due to the spread of grape stalk were included.
}

Table 4

Data inventory for bottling and packaging (data related to FU).

\begin{tabular}{llc}
\hline & Units & \\
\hline Inputs & $\mathrm{l}$ & \\
Wine & $\mathrm{kg}$ & 0.75 \\
White glass & $\mathrm{g}$ & 0.56 \\
Cork & $\mathrm{g}$ & 3.5 \\
Paper for labels & $\mathrm{g}$ & 1 \\
Corrugated board & & 66.7 \\
Outputs & & \\
Product & $\mathrm{p}$ & 1 \\
$\quad$ Bottle of wine & $\mathrm{g}$ & \\
$\quad$ Gaste & $\mathrm{g}$ & 14 \\
\hline
\end{tabular}

White glass bottles were assumed to be manufactured out of approximately $61 \%$ recycled glass. This value was retrieved from the Ecoinvent database (version 2.2) for white packaging glass.

\subsubsection{Glass bottle disposal}

Different waste scenarios for glass bottle were considered, coherently with distribution destinations; therefore, three waste scenarios were chosen: Italian, European and American. In Italy, $34 \%$ of the glass is landfilled and 66\% is recycled (Co.Re.Ve.), while in Europe an average of $32 \%$ of the glass is landfilled and 68\% is recycled (FEVE (The European Container Glass Federation)), and $72 \%$ of the glass is landfilled and $28 \%$ is recycled in the United States (CRI (Container Department Institute)).

\subsubsection{Allocation}

During the wine making process, other products besides wine are produced: marc, lees and stalks. Marc and lees are sold to a distillery; stalks are, as previously mentioned, spread on the field.

An allocation was made on an economic basis since the economic value best reflects the relative importance of the different co-products within the wine industry (Gazulla et al., 2010). Table 5 reports the economic allocation factors used, as well as the mass share of each coproduct, as indicated by the company.

\subsubsection{Transport}

To date, few studies have included the distribution phase in wine life cycle assessments; among them, the following could be cited: Aranda et al. (2005); Ardente et al. (2006); Gonzalez et al. (2006); Petti et al. (2006); CIV (2008); Gazulla et al. (2010); Barry (2011); Bosco et al. (2011); Point et al. (2012); and Burja and Burja (2012). Since transport can be relevant in the overall environmental impact of wine (Colman and Päster, 2009; Saxe, 2010; OIV (International Organisation of Vine and Wine), 2013), it was decided to include this phase in our study, following the guidelines established by the Product Environmental Footprint (PEF) Guide (Manfredi et al., 2012).

Wine bottles are distributed within national borders and abroad. Due to the lack of information regarding international distribution, the transportation phase was neglected in the Level A analysis, with the aim of not reducing the reliability of the results.

Table 5

Allocation factors and mass share.

\begin{tabular}{lcc}
\hline Product & Mass \% & Economic allocation factor (\%) \\
\hline Wine & 70 & 99.95 \\
Marc and lees & 25 & 0.05 \\
Stalk & 5 & 0
\end{tabular}




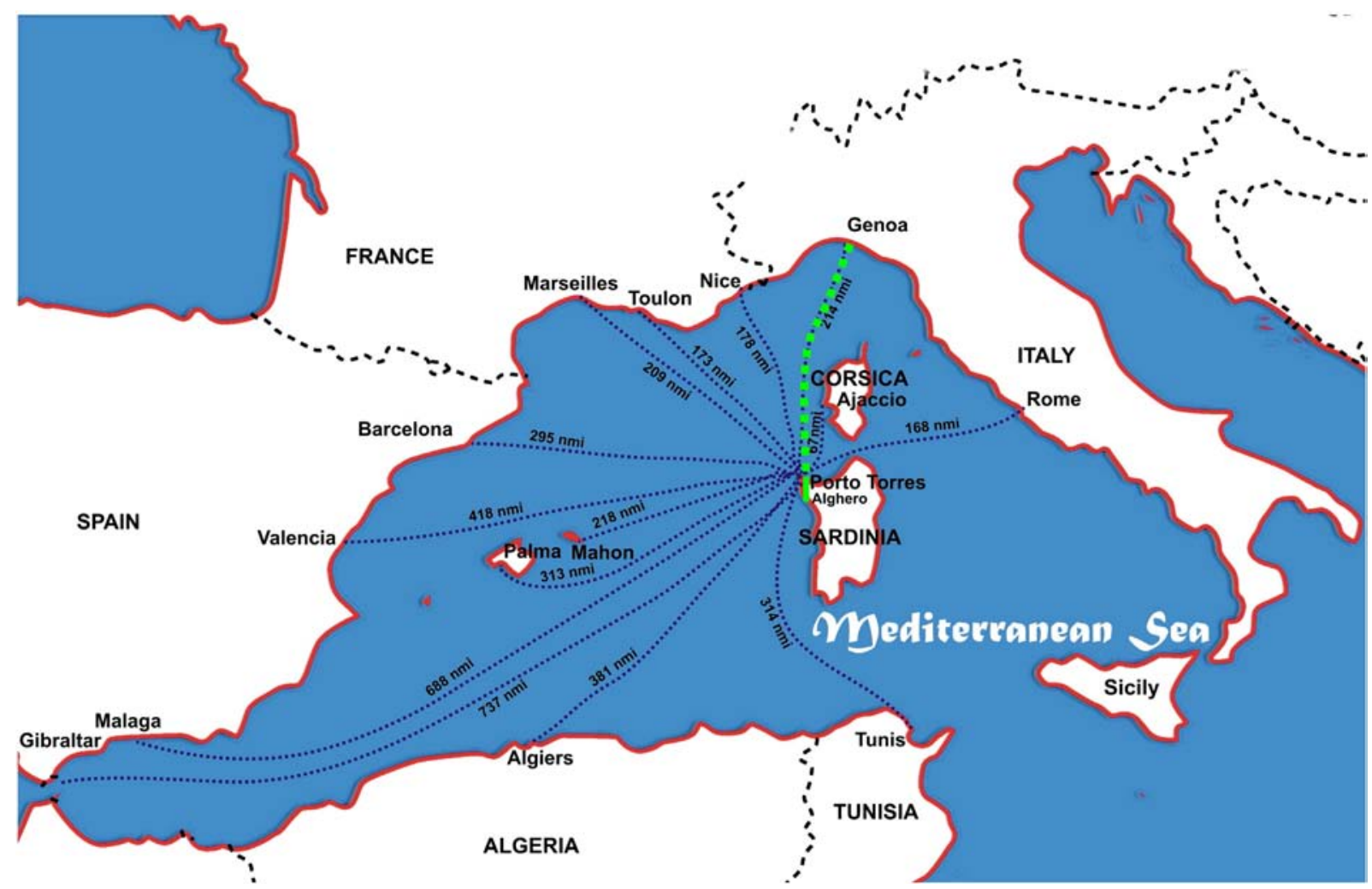

Fig. 2. Itinerary from Alghero to Porto Torres (by road) and from Porto Torres to Genoa (by sea). Common itinerary for all distribution destinations outside Sardinia. Source: Autorità Portuale di Olbia e Golfo Aranci

Some assumptions were made in order to perform the Level B analysis, in order to have an estimation of the transportation phase impacts, and their role in the overall wine life cycle assessment.

Apart from Sardinian distribution, which was performed only by road transportation, the distribution in all other destinations (within national borders (the Italian peninsula), and abroad) presented two common aspects (Fig. 2):

1 Transportation by road from Alghero (where the company is located) to Porto Torres;

2 Transportation by sea from Porto Torres to Genoa.

As for national distribution (Sardinia and the Italian peninsula), the specific destination (final destination or distribution centre) was available. Thus, it was possible to calculate the accurate amount of kilometres covered by the product both overland and by sea.

Information regarding international distribution was limited to destination countries and transportation means (Autorità Portuale di Genova). Therefore, it was possible to calculate the accurate number of kilometres covered by the product overland and by sea only until the Genoa port. Since no other precise information (from Genoa to the final destinations) was available, it was decided to calculate an "average point" of destination within each country. Instead of taking as a destination point the capital of the country or a place in the middle of the country, it was decided to estimate an average destination place, calculated by taking into account the distance from Genoa to the ten most populated cities of each country (Office for National Statistics; FSO (Federal Statistical Office); Statistical Offices of the Länder). Therefore, the

Table 6

Distribution destinations and transportation means.

\begin{tabular}{|c|c|c|c|c|c|}
\hline & & & & Transportation means & $\%$ total production \\
\hline \multirow[t]{10}{*}{ National distribution } & Sardinia & Cagliari & Lorry $>32 \mathrm{t}$ & 9.7 & 30 \\
\hline & & Carbonia-Iglesias & & 0.3 & \\
\hline & & Nuoro & & 0.2 & \\
\hline & & Ogliastra & & 0.1 & \\
\hline & & Oristano & & 1.6 & \\
\hline & & Olbia-Tempio & & 4.9 & \\
\hline & & Sassari & & 5.9 & \\
\hline & & Medio Campidano & & 7.2 & \\
\hline & Peninsula & Frascati (Roma) ${ }^{\mathrm{a}}$ & Lorry $>32 \mathrm{t}$, container ship & 6.8 & 22 \\
\hline & & Canale (Cuneo) $)^{\mathrm{a}}$ & & 15.2 & \\
\hline \multirow[t]{4}{*}{ National distribution } & Europe & England & Lorry $>32 \mathrm{t}$, container ship & 5.5 & 48 \\
\hline & & Germany & & 38.3 & \\
\hline & & Switzerland & & 4 & \\
\hline & United States & & Lorry $>32 \mathrm{t}$, container ship & 52.2 & \\
\hline
\end{tabular}

\footnotetext{
a Distribution centre.
} 
Table 7

Parameters and respective changes considered in the sensitivity analysis.

\begin{tabular}{|c|c|c|c|c|}
\hline & & \multirow{2}{*}{$\begin{array}{l}\text { Default } \\
\text { value }\end{array}$} & \multicolumn{2}{|l|}{ Range } \\
\hline & & & Min & Max \\
\hline & & \multicolumn{3}{|c|}{$\mathrm{kg} \mathrm{N} \mathrm{N}_{2} \mathrm{O}-\mathrm{N} / \mathrm{kg} \mathrm{N}$} \\
\hline \multirow[t]{7}{*}{$\begin{array}{l}\text { Fertiliser } \\
\text { used }\end{array}$} & $\begin{array}{l}\mathrm{N}_{2} \mathrm{O} \text { emission factor from all } \mathrm{N} \text { inputs } \\
\text { (direct emissions) }\end{array}$ & 0.01 & 0.003 & 0.03 \\
\hline & $\begin{array}{l}\mathrm{N}_{2} \mathrm{O} \text { emission factor from } \mathrm{N} \text { volatilization } \\
\text { and re-deposition }\end{array}$ & 0.01 & 0.002 & 0.05 \\
\hline & $\mathrm{N}_{2} \mathrm{O}$ emission factor from leaching & 0.0075 & 0.0005 & 0.025 \\
\hline & & $\begin{array}{l}\text { Share of } \\
\text { transfer }\end{array}$ & which is & \\
\hline & Volatilization for synthetic fertiliser & 0.10 & 0.03 & 0.30 \\
\hline & Volatilization for organic fertiliser & 0.20 & 0.05 & 0.50 \\
\hline & $\mathrm{N}$ losses by leaching & 0.30 & 0.10 & 0.80 \\
\hline \multirow[t]{4}{*}{ LPG used } & & $\mathrm{mg} / \mathrm{MJ}$ & & \\
\hline & $\mathrm{CO}_{2}$ emission factor & 63,100 & 61,600 & 65,600 \\
\hline & $\mathrm{CH}_{4}$ emission factor & 1 & 0.3 & 3 \\
\hline & $\mathrm{N}_{2} \mathrm{O}$ emission factor & 0.1 & 0.03 & 0.3 \\
\hline
\end{tabular}

destination point obtained represents an average place within the most populated cities of each country considered (Supplementary data: Tables 1, 2 and 3). The assumption made as the basis of this decision was as follows: imported wine is more likely to be in demand in cities with a higher number of inhabitants.

As for U.S. distribution, nautical miles from Genoa to New York port were calculated; New York port was selected, among all American ports, as the most connected to the port of Genoa (Genoa Port Authority Offi- cial Data, 2012). Due to the lack of information, the U.S. distribution was only considered until the port of New York; transport from the port to other possible destinations was excluded. Table 6 lists the destinations of wine bottles, both within national borders and abroad, and the transportation means considered in the analysis in accordance with the information provided by the company.

\subsection{Impact assessment}

SimaPro (version 7.3.2) was used to model the life cycle of Vermentino wine. Consistently with other studies (Aranda et al., 2005; Petti et al., 2010; Gazulla and Raugei, 2010; Vázquez-Rowe et al., 2012; Point et al., 2012; Benedetto, 2013), the following impact categories were selected to evaluate the environmental impact of the wine under study: global warming potential (GWP), acidification potential, eutrophication potential, photochemical ozone creation potential, ozone layer depletion (ODP) and abiotic depletion. LCIA was carried out using the CML baseline 2000 method (Guinée et al., 2002).

\subsection{Sensitivity analysis}

A set of parameters was changed and its influence on the results was evaluated. The most uncertain parameters were taken into account to run the sensitivity analysis. Consistently with Neto et al. (2013), in the agricultural phases, the parameters associated with the emission of nitrogen compounds due to fertiliser use were considered. For the wine production phase, the emission factors of carbon dioxide, methane and

Table 8

Results (expressed in absolute values and in percentage of contribution) from the characterisation step presented for each impact category.

\begin{tabular}{|c|c|c|c|c|c|c|c|c|}
\hline \multirow[t]{2}{*}{ Impact categories } & \multirow[t]{2}{*}{ Units } & \multicolumn{2}{|c|}{ Agricultural phase } & \multicolumn{2}{|c|}{ Wine making phase } & \multicolumn{2}{|c|}{ Bottling and packaging } & \multirow[t]{2}{*}{ Total value } \\
\hline & & Value & $\%$ over total & Value & $\%$ over total & Value & $\%$ over total & \\
\hline Abiotic depletion & kg Sb eq. & $2.57 \mathrm{E}-03$ & 34.19 & $7.61 \mathrm{E}-04$ & 10.10 & $4.19 \mathrm{E}-03$ & 55.71 & $7.53 \mathrm{E}-03$ \\
\hline Acidification & $\mathrm{kg} \mathrm{SO}{ }_{2}$ eq. & $1.52 \mathrm{E}-03$ & 22.13 & $8.46 \mathrm{E}-04$ & 12.29 & $4.51 \mathrm{E}-03$ & 65.58 & $6.88 \mathrm{E}-03$ \\
\hline Eutrophication & $\mathrm{kg} \mathrm{PO}_{4}$-eq. & $3.22 \mathrm{E}-04$ & 35.75 & $1.67 \mathrm{E}-04$ & 18.55 & $4.12 \mathrm{E}-04$ & 45.70 & $9.02 \mathrm{E}-04$ \\
\hline Global warming (GWP100) & $\mathrm{kg} \mathrm{CO}$ eq. & $1.69 \mathrm{E}-01$ & 16.86 & $2.74 \mathrm{E}-01$ & 27.23 & $5.62 \mathrm{E}-01$ & 55.91 & $1.01 \mathrm{E}+00$ \\
\hline Ozone layer depletion (ODP) & kg CFC-11 eq. & $1.58 \mathrm{E}-07$ & 71.04 & $5.51 \mathrm{E}-09$ & 2.48 & $5.89 \mathrm{E}-08$ & 26.48 & $2.23 \mathrm{E}-07$ \\
\hline Photochemical oxidation & $\mathrm{kg} \mathrm{C}_{2} \mathrm{H}_{4}$ eq. & $7.54 \mathrm{E}-05$ & 28.12 & $9.74 \mathrm{E}-05$ & 28.31 & $1.60 \mathrm{E}-04$ & 49.77 & $3.44 \mathrm{E}-04$ \\
\hline
\end{tabular}

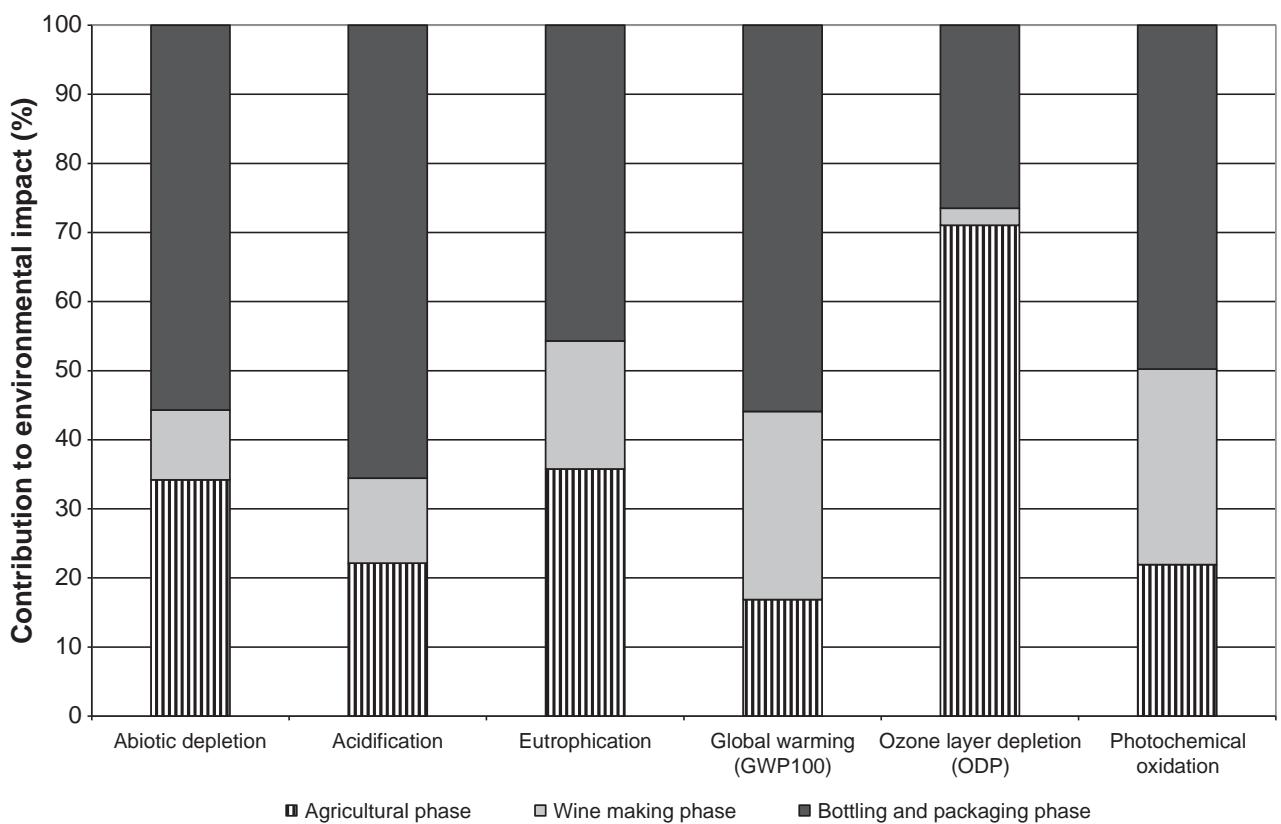

Fig. 3. Contribution of each phase (agricultural, wine making and bottling and packaging phase) to produce one bottle of wine. 


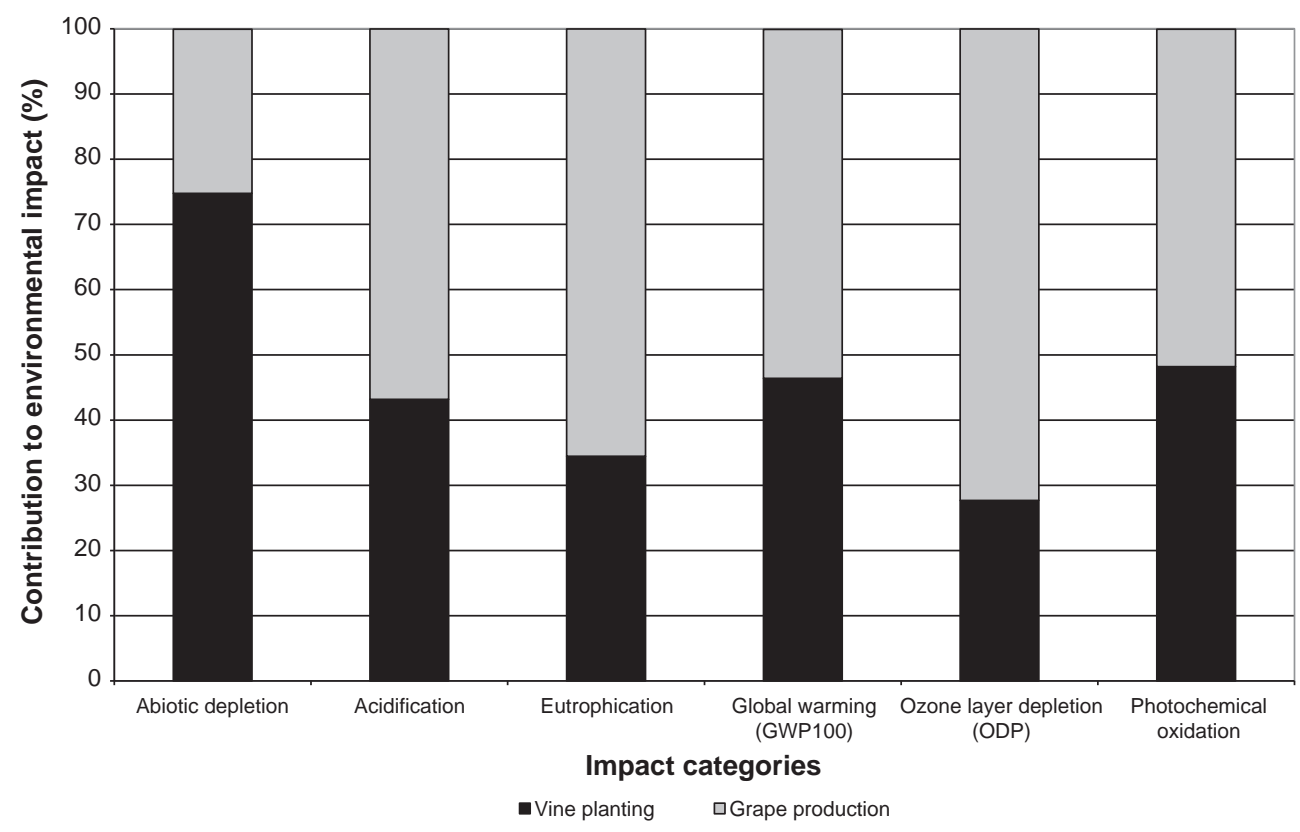

Fig. 4. Contribution of vine planting and grape production to the agricultural phase impact.

dinitrogen monoxide related to the use of LPG were changed. The emission factors both for fertiliser emissions and LPG emissions were modified within the range defined in the IPCC (2006a,b) (minimum and maximum value). The analysis was carried out considering, firstly, all minimum values of emission factors and, secondly, all maximum values (Table 7).

\section{Results and discussion}

\subsection{Level A}

Table 8 reports the total and relative impact values per FU linked to the three processes under study: the agricultural phase (vine planting and grape production), the wine making phase and the bottling and packaging phase. Fig. 3 shows the contribution of each phase to the production of one bottle of wine. The wine bottle disposal accounted for less than $0.5 \%$ of the overall environmental impact for all of the impact categories, so it was not considered a relevant process.

The bottling and packaging phase represented the main contributor to all impact categories except for ozone layer depletion, for which the agricultural phase played the most important role. The principal carrier of environmental impact was glass bottle production, for all impact categories (consistent with the results obtained by Petti et al. (2006)).

Although the system boundaries were changed compared to the previous study (Benedetto, 2013), the use of glass bottles remains a key node in the company production process.

As for the agricultural phase and the wine making phase, the following considerations could be made. Abiotic depletion is due to the consumption of fossil-based energy resources, mainly used in the agricultural phase (as diesel fuel) and, secondly, in the wine making phase (as electricity consumption and LPG use). Acidification, which is mostly related to the emission of $\mathrm{SO}_{2}$ and $\mathrm{NO}_{\mathrm{x}}$ to air, was, for the major part, caused by the use of electricity and diesel fuel and by diesel combustion for agricultural operations. Eutrophication was primarily associated with emissions due to fertiliser use in the agricultural phase and with wastewater produced during the wine making process. With regard to GWP, the main contributors were diesel fuel production and consumption (agricultural phase) and electricity consumption (wine making phase). ODP impacts were primarily associated with the emissions related to the production of pesticides used in the agricultural phase. For photochemical oxidation, the contributions of the agricultural phase (due to diesel fuel and pesticide production) and the wine making phase (due to ethanol emissions during the fermentation process) were similar.

With respect to other studies (Neto et al., 2013; Vázquez-Rowe et al., 2012), the contribution to the overall impact assessment of the agricultural phase and the wine making phase was lower for all impact categories except ODP (which was found to be consistent). On the other hand, the burden of bottling and packaging was higher.

The lower amount of fertilisers used and wastewater produced in the present study may have determined a reduction of the eutrophication associated with agricultural and wine making phases. The same consideration could be stated for abiotic depletion, acidification and GWP; in these cases, the inputs involved were electricity and LPG (lower with respect to the above mentioned studies) and diesel fuel consumption (lower with respect to the study carried out by Neto et al. (2013)). As for the GWP value (1.01 $\mathrm{kg} \mathrm{CO}$-eq./bottle), it was found to be consistent with the results obtained by Ardente et al. (2006), Gazulla et al. (2010) and Bosco et al. (2011), which lie between 0.6 and $1.3 \mathrm{~kg} \mathrm{CO}$-eq./bottle, and the results obtained in other winerelated studies (Vázquez-Rowe et al., 2013) in which the GHG emissions per bottle were between 0.65 and $1.17 \mathrm{~kg} \mathrm{CO}_{2}$-eq.

As already specified, the agricultural phase of the present study included two sub-phases: vine planting and grape production. The

Table 9

Sensitivity analysis results, calculated for the characterisation step, expressing the changes for each impact category with respect to the reference case.

\begin{tabular}{|c|c|c|c|c|}
\hline \multirow[t]{2}{*}{ Impact categories } & \multirow{2}{*}{$\begin{array}{l}\begin{array}{l}\text { Agricultural } \\
\text { phase }\end{array} \\
\text { Variation \% }\end{array}$} & \multirow{2}{*}{$\begin{array}{l}\text { Wine making } \\
\text { phase } \\
\text { Variation \% }\end{array}$} & \multirow{2}{*}{$\begin{array}{l}\text { Bottling and } \\
\text { packaging }\end{array}$} & \multirow[t]{2}{*}{$\begin{array}{l}\text { Total } \\
\text { variation \% }\end{array}$} \\
\hline & & & & \\
\hline Abiotic depletion & 0 & 0 & 0 & 0 \\
\hline Acidification & $\begin{array}{l}-6.51 \\
+19.13\end{array}$ & 0 & 0 & $\begin{array}{l}-1.44 \\
+4.20\end{array}$ \\
\hline Eutrophication & $\begin{array}{l}-19.13 \\
+50.78\end{array}$ & 0 & 0 & $\begin{array}{l}-6.84 \\
+18.20\end{array}$ \\
\hline $\begin{array}{l}\text { Global warming } \\
\text { (GWP100) }\end{array}$ & $\begin{array}{l}-1.79 \\
+7.08\end{array}$ & $-0.02,+0.03$ & 0 & $\begin{array}{l}-0.31 \\
+1.20\end{array}$ \\
\hline $\begin{array}{l}\text { Ozone layer } \\
\text { depletion (ODP) }\end{array}$ & 0 & 0 & 0 & 0 \\
\hline $\begin{array}{c}\text { Photochemical } \\
\text { oxidation }\end{array}$ & 0 & 0 & 0 & 0 \\
\hline
\end{tabular}




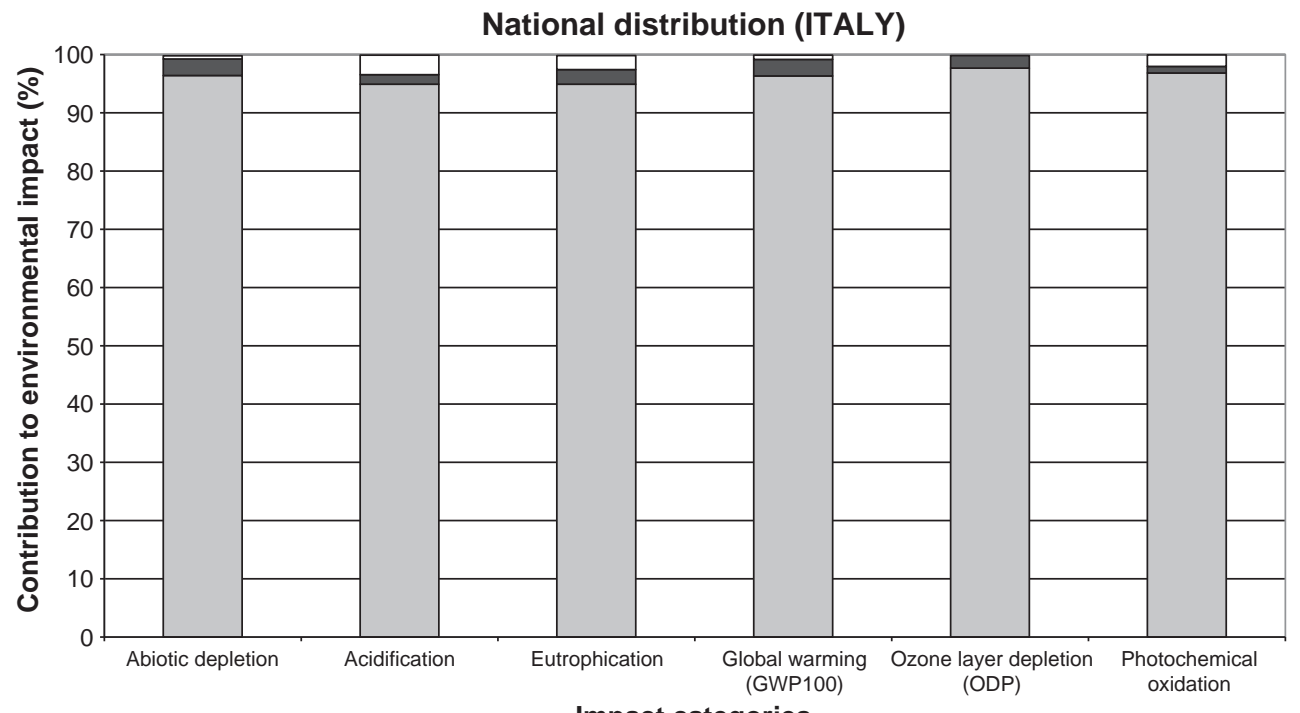

Impact categories

$\square$ Bottle of Wine $\quad \square$ Transport, lorry $>32 t \quad \square$ Container ship

International distribution (EUROPE)

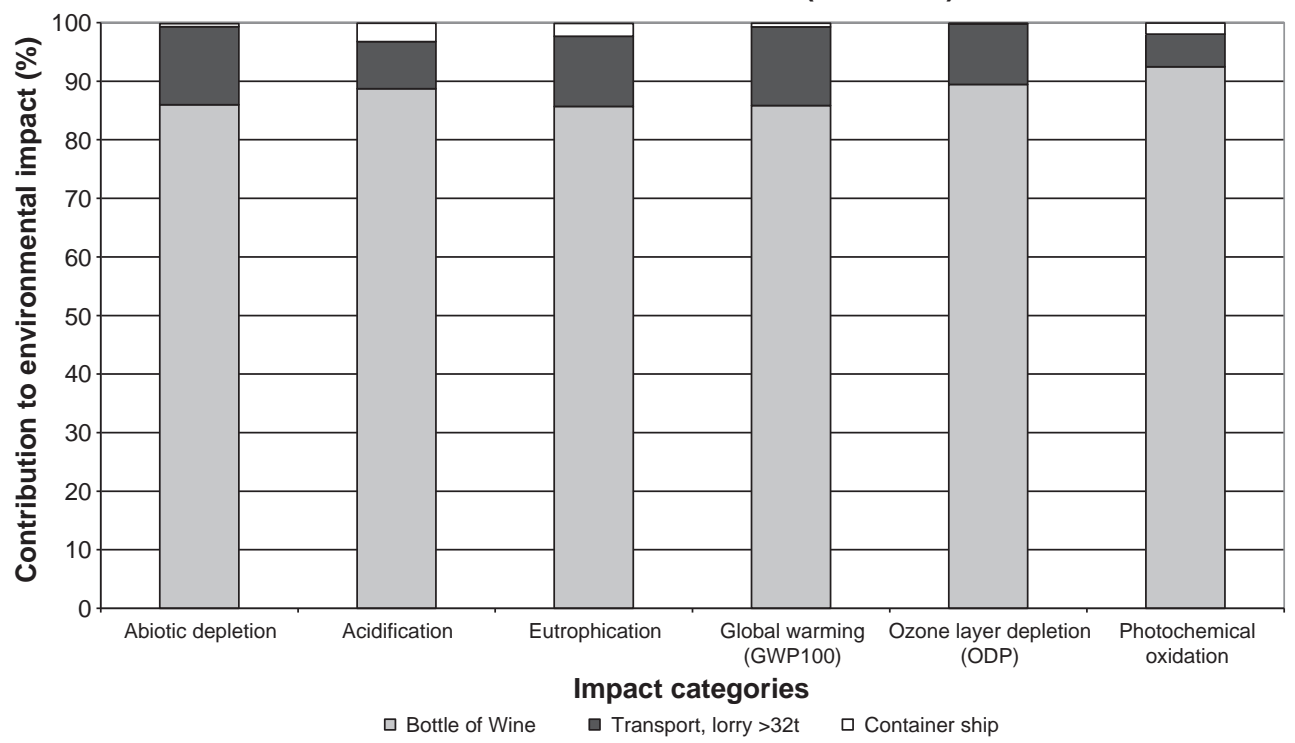

International distribution (USA)

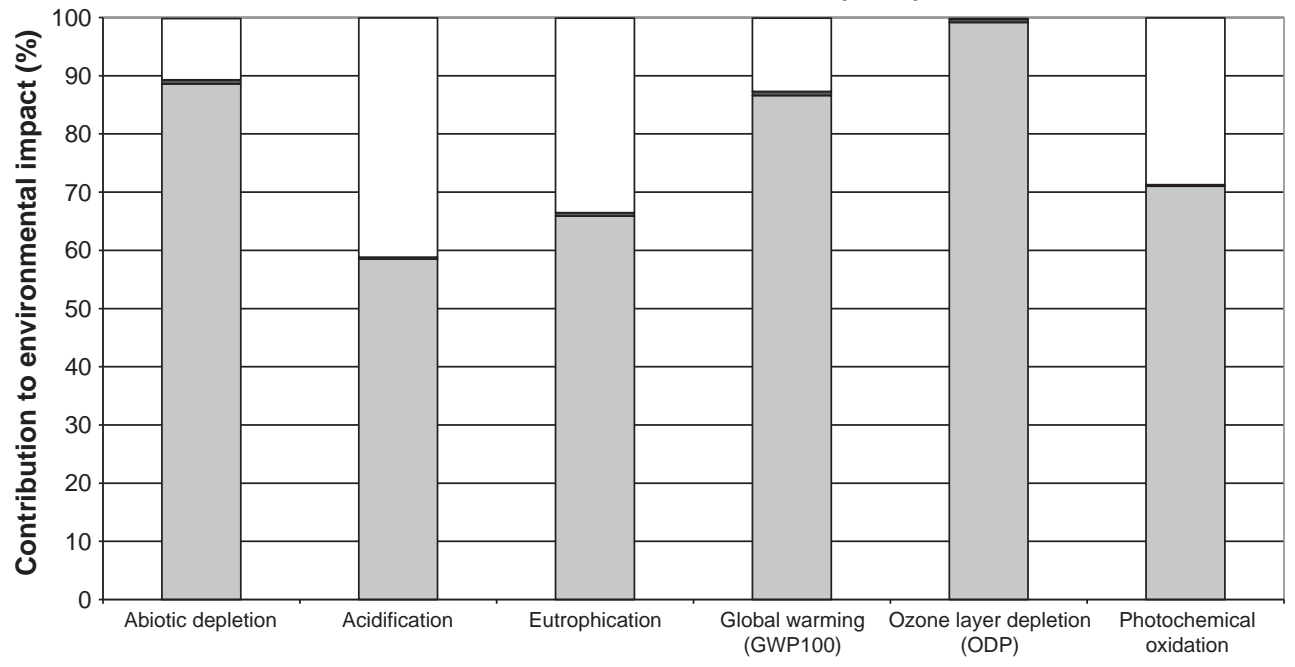

Impact categories

$\square$ Bottle of Wine $\quad$ - Transport, lorry $>32 t \quad \square$ Container ship

Fig. 5. Results with the inclusion of the transportation phase (percentage contribution to each impact category of the bottle of wine production and transportation phase). 
contributions of these sub-phases are shown in Fig. 4. Vine planting had a great influence on the environmental performance of the whole agricultural phase. The main contributor in the vine planting phase to the impact categories considered was the production of diesel fuel needed for field operations (above all: land preparation and trellis laying), which is consistent with the results obtained by Petti et al. (2006), Bosco et al. (2011) (for the GWP category impact) and Benedetto (2013). The contribution of diesel fuel production to environmental impact varied between $85 \%$ (abiotic depletion) and $40 \%$ (eutrophication).

The agricultural phase is the stage where the largest sensitivities were found. The variation of the sensitivity parameters had large effects on the eutrophication impact category, which was primarily associated with emissions due to the use of fertilisers. Changes in parameters related to the emission of nitrogen compounds resulting from the use of organic and synthetic fertilisers affected eutrophication. Changes in the emission factors for LPG combustion resulted in small changes for global warming. Pesticide emissions were not found to be relevant, regardless of the percentage value used to calculate them. Table 9 shows the results of the sensitivity analysis.

\subsection{Level $B$}

The results obtained with the inclusion of the transportation phase are shown in Fig. 5 and in the Supplementary documents (Tables 5, 6 and 7). The impact due to the distribution of one bottle of wine within national borders (Italy) was maximum (5\%) for acidification and eutrophication. Data concerning the transportation phase in Italy were provided by the company; therefore, the results were considered reliable.

As for international distribution (Europe, Italy excluded, and USA), the environmental burden associated with transportation increased, as expected. In particular, transportation by sea over long distances (USA) appeared to have a relevant impact on almost all of the impact categories taken into consideration: $41 \%$ for acidification, $33 \%$ for eutrophication, $29 \%$ for photochemical oxidation, $12 \%$ for global warming potential and $10 \%$ for abiotic depletion. Data concerning international distribution were, however, estimated; therefore, the results obtained have to be considered a rough indication of the role played by the transportation phase on the overall life cycle of a bottle of wine.
The comparison between level A and level B results is shown in Fig. 6. Distribution within national borders caused an increase in environmental impacts of less than $5 \%$ with respect to the A scenario for all of the impact categories. European distribution determined a worse environmental performance in every impact category considered, in particular for abiotic depletion (14\% increase with respect to level A results), global warming potential (12\%) and ozone layer depletion (10\%). US distribution was responsible for a consistent increase in the environmental burden, especially for acidification, eutrophication and photochemical oxidation impact categories. It has to be taken into account that the results for US distribution would have been worse if road transportation within the country had also been taken into account.

\section{Conclusions}

The study carried out evaluates the environmental impacts associated with viticulture, vinification, bottling and packaging in a Sardinian winery. The results showed that the environmental performance of a bottle of Vermentino wine was mostly determined by glass bottle production. Therefore, a reasonable option to reduce the environmental impact of the product would be to use a lighter glass bottle (Aranda et al., 2005; Point et al., 2012; Cleary, 2013) or to substitute the glass bottle with an aseptic carton, although this alternative would require an impact analysis on the chemical and flavour characteristics of the wine (Montedonico, 2005). A study carried out by Pasqualino et al. (2011) showed in fact that, between the glass and aseptic carton options for juice packaging, the second solution had a lower impact on the two environmental categories considered (GWP and Cumulative Energy Demand). The adoption of a lighter container (lighter glass bottle or aseptic carton) would benefit the distribution phase as well; this advantage is proportional to the distance of transportation required. The distribution phase was shown to affect the environmental results as the distance of transportation increased.

The availability of vine planting data allowed us to perform an environmental analysis on the whole agricultural phase involved in the production of grapes. The results showed that the vine planting sub-phase was not negligible given its contribution to the agricultural phase.

The results obtained were compared with other wine-related LCA studies. However, as stated by Neto et al. (2013), the results are not

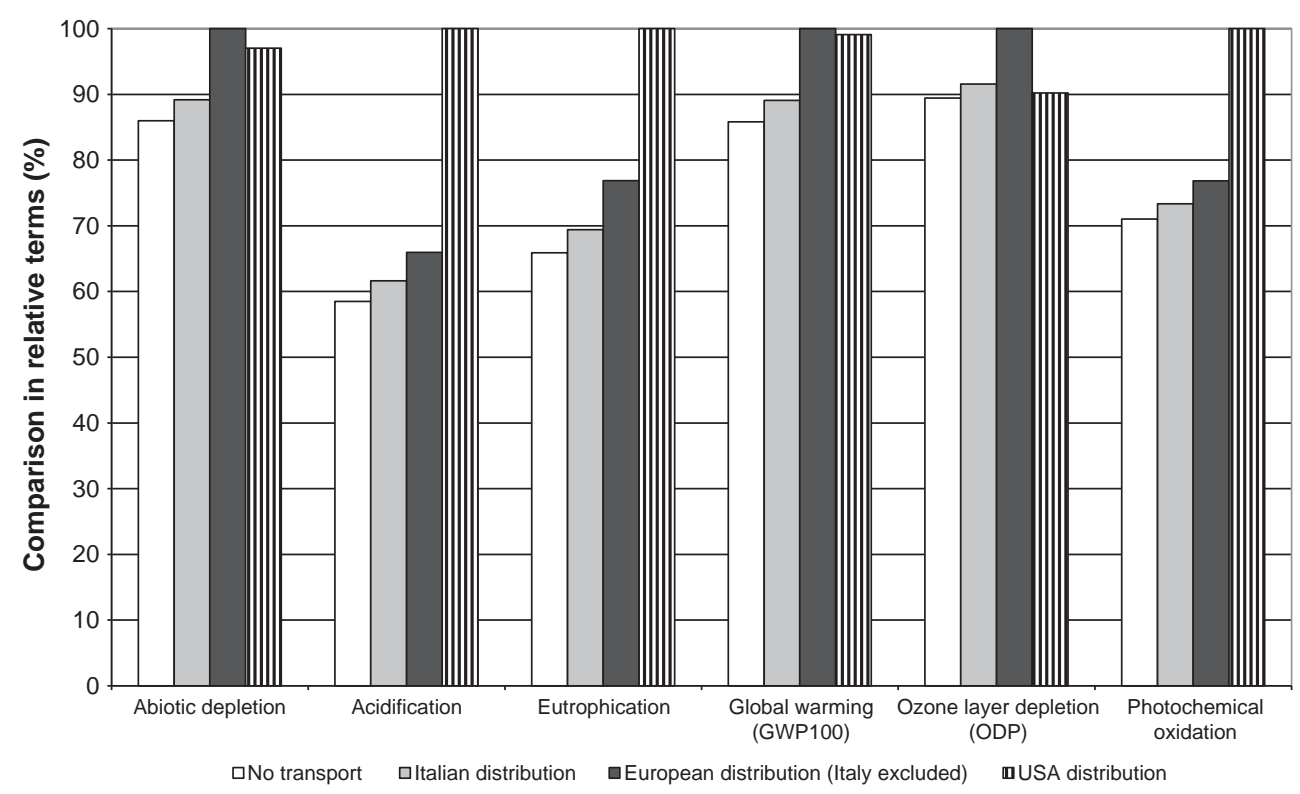

Fig. 6. Comparison between level A and level B results. 
easily comparable due to the methodological options available (i.e. the method used to estimate emissions) and the different protocols used to produce the wine. Therefore, harmonised rules allowing a comparison of the results of different studies are needed.

\section{Acknowledgement}

The authors wish to thank dott. Stefano Biscaro and the Sella \& Mosca for their precious cooperation in providing accurate and reliable data useful in drawing up of the study.

This is the author's contribution: Graziella Benedetto (GB) was responsible for the conception and design. GB had conceived the questionnaire and collected all the data with input from Alessandra Fusi (AF); AF elaborated the data which were interpreted with GB. GB wrote the introduction and results and discussion; AF wrote materials and methods and results and discussion. All authors contributed to writing conclusion. The authors approved the final version.

\section{Appendix A. Supplementary data}

Supplementary data to this article can be found online at http://dx. doi.org/10.1016/j.scitotenv.2013.11.148.

\section{References}

Andersson I. Environmental management tools for SMEs: a handbook. Environmenta issues series. European Environment Agency; 1998.

Aranda A, Scarpellini S, Zabalza I. Economic and environmental analysis of the wine bottle production in Spain by means of life cycle assessment. Int J Agric Resour Gov Eco 2005;4:178-91.

Ardente F, Beccali G, Cellura M, Marvuglia A. POEMS: a case study of an Italian wine-producing firm. Environ Manag 2006;3:350-64.

Audsley E. Harmonization of environmental life cycle assessment for agriculture. European Commission DG VI Agriculture. Silsoe: Silsoe Research Institute; 1997.

Autorità Portuale di Genova. http://servizi.porto.genova.it/traffici/statistiche/quota_ principali_porti_collegati/dettaglio.aspx?id=11118. [last visit 21/05/2013]

Barber N, Taylor C, Strick S. Wine consumers' environmental knowledge and attitudes: influence on willingness to purchase. Int J Wine Res 2009;1:59-72.

Barry MT. Life cycle assessment and the New Zealand wine industry: a tool to support continuous environmental improvement. Wellington, New Zealand: Massey University; 2011 [Master thesis].

Benedetto G. The environmental impact of a Sardinian wine by partial life cycle assessment. Wine Econ Policy 2013;2:33-41.

Benedetto G, Corinto G, Rugani B, Vázquez-Rowe I, Benetto E. The evolution of life cycle assessment (LCA): some guidelines for future research in the wine sector. Proceedings of the L Annual Meeting of SIDEA, Lecce 26-28 September 2013; 2013.

Berners-Lee M, Howard DC, Moss J, Kaivanto KWA, Scott WA. Greenhouse gas footprinting for small businesses-the use of input-output data. Sci Total Environ 2011;409:883-91.

Bosco S, Di Bene C, Galli M, Remorini D, Massai R, Bonari E. Greenhouse gas emissions in the agricultural phase of wine production in the Maremma rural district in Tuscany, Italy. Ital J Agron 2011;6:93-100

Burja C, Burja V. Decisions in sustainable viticulture using life cycle assessment. J Environ Prot Ecol 2012;13(3):1570-7.

Carta G. Evaluation of environmental sustainability of two Italian wine productions through the use of the life cycle assessment (LCA) method. Italy: University of Sassari; 2009 [Master thesis, in Italian].

CEC (Commission of the European Communities). Communication from the Commission to the European Parliament, the Council, the European Economic and Social Committee and the Committee of the Regions. Integrated product policy. Building on environmental life-cycle thinking. COM(2003)302 final. Brussels, Belgium: CEC; 2003.

Cerutti AK, Bruun S, Beccaro GL, Bounous G. A review of studies applying environmental impact assessment methods on fruit production systems. J Environ Manag 2011;92: 2277-86.

CIV-Consorzio Interprovinciale Vini s.c.agr. Environmental product declaration (EPD) and climate declaration-bottled red sparkling wine "Gasparossa Righi", validated EPD N S-P-00109, Rev. March 2008, IT. http://www.environdec.com/, 2008.

Cleary J. Life cycle assessment of wine and spirit packaging at the product and the municipal scale: a Toronto, Canada case study. J Clean Prod 2013;44:143-51.

Coderoni S, Bonati G. Impronta carbonica delle aziende agricole italiane. INEA; 2013.

Colman T, Päster P. Red, white, and 'green': the cost of greenhouse gas emissions in the global wine trade. J Wine Res 2009;20(1):15-26.

COREVE (Consorzio Recupero Vetro). Programma Specifico di Prevenzione 2010 (Risultati di riciclo 2009); 2010

CRI (Container Department Institute). http://www.container-recycling.org/. [last visit 29/03/2013].
DETEC (Federal Department of the Environment, Transport, Energy and Communications). http://www.bafu.admin.ch/index.html?lang=it. [last visit 05/02/2013].

Dick J, Smith P, Smith R, Lilly A, Moxey A, Booth J, et al. Calculating farm scale greenhouse gas emissions. Scotland, UK: University of Aberdeen, Carbon Plan, the Macaulay Institute, Pareto Consulting, SAOS Ltd.; 2008.

EMEP/EEA. Agriculture other (use of pesticides and limestone). Air pollutant emission inventory guidebook 2013 -technical report no 12/2013. Copenhagen: European Environment Agency; 2013.

ENVIFOOD Protocol Environmental Assessment of Food and Drink Protocol. European Food Sustainable Consumption \& Production Round Table, draft version 0.1, for pilot testing -November 2012; 2012.

FEVE (The European Container Glass Federation). http://www.feve.org/. [last visit 29/03/2013].

Frischknecht R, Jungbluth N, Althaus HJ, Doka G, Heck T, Hellweg S, et al. Overview and methodology. Ecoinvent report no. 1. Dübendorf: Swiss Centre for Life Cycle Inventories; 2007.

FSO (Federal Statistical Office). http://www.bfs.admin.ch/bfs/portal/en/index.html. [last visit 02/05/2013]

Gazulla C, Raugei M, Fullana-i-Palmer P. Taking a life cycle look at Crianza wine production in Spain: where are the bottlenecks? Int J Life Cycle Assess 2010;15:330-7.

Gonzalez A, Klimchuk A, Martin M. Life cycle assessment of wine production process. Finding relevant process efficiency and comparison to eco-wine production, 1N1800 life cycle assessment, group 4; 2006.

González-García S, Castanheira EG, Dias AC, Arroja L. Environmental life cycle assessment of a dairy product: the yoghurt. Int J Life Cycle Assess 2013a;8:796-811.

González-García S, Castanheira EG, Dias AC, Arroja L. Using life cycle assessment methodology to assess UHT milk production in Portugal. Sci Total Environ 2013b;442: 225-34.

Guidetti R L'analisi energetica come indicatore di processo nel settore enologico. In: Blandini G, Manetto G, editors. [s.1]: GeoGeografica, 2005 Jun(Convegno AIIA2005, L'ingegneria agraria per lo sviluppo sostenibile dell'area mediterranea tenutosi a Catania, 27-30 Giugno 2005)88-901860-0-3; 2005.

Guinée JB, Gorrée M, Heijungs R, Huppes G, Kleijn R, Koning A, et al. Handbook on life cycle assessment. Operational guide to the ISO standards. I: LCA in perspective. Ila: Guide. IIb: operational annex. III: scientific background. Dordrecht: Kluwer Academic Publishers; 2002 [692 pp.].

Intergovernmental Panel on Climate Change (IPCC). IPCC Guidelines for National Greenhouse Gas Inventories Agriculture, Forestry and Other Land Use, Chapter 11: $\mathrm{N}_{2} \mathrm{O}$ emissions from managed soils, and $\mathrm{CO}_{2}$ emissions from lime and urea application, vol. 4. IPCC; 2006 a

Intergovernmental Panel on Climate Change (IPCC). IPCC Guidelines for National Greenhouse Inventories Energy, Chapter 2: stationary combustion, vol. 2. IPCC; 2006b.

Iribarren D, Vázquez-Rowe I, Hospido A, Moreira MT, Feijoo G. Estimation of the carbon footprint of the Galician fishing activity (NW Spain). Sci Total Environ 2010;408: 5284-94.

ISO. ISO 14040. Environmental management - life cycle assessment - principles and framework. International Organization for Standardization; 2006a.

ISO. ISO 14044. Environmental management - life cycle assessment - requirements and guidelines. International Organization for Standardization; 2006b.

Lambert G. Carbon neutral wine -Australian winery's ISO 14044 vintage. ISO Focus +, July-August: 34-35; 2010

Manfredi S, Allacker K, Chomkhamsri K, Pelletier N, Maia de Souza D. Product environmental footprint guide; consolidated version. Deliverable 2 and $4 \mathrm{~A}$ of the Administrative Arrangement between DG Environment and the Joint Research Centre No N 070307/2009/552517, including Amendment No 1 from December 2010. European Commission (EC), Joint Research Centre (JRC), Institute for Environment and Sustainability (IES). Ref. Ares; 2012 [873782 - 17/07/201].

Margni M, Rossier D, Crettaz P, Jolliet O. Life cycle impact assessment of pesticides on human health and ecosystems. Agric Ecosyst Environ 2002;93:379-92.

Montedonico CM. The life cycle assessment (LCA) of a Chilean cabernet sauvignon wine bottle. (Master thesis) Revista ECOENGEN, Articulo no. 04, 2009, Santiago, Chile. Italy: University of Bologna; 2005.

Neto B, Dias AC, Machado M. Life cycle assessment of the supply chain of a Portuguese wine: from viticulture to distribution. Int J Life Cycle Assess 2013;18: 590-602.

Nielsen PH, Nielsen AM, Weidema BP, Dalgaard R, Halberg N. LCA food data base. www. lcafood.dk, 2003.

Notarnicola B, Tassielli G, Nicoletti GM. Life cycle assessment (LCA) of wine production. In: Mattson B, Sonesson U, editors. Environmentally-friendly food processing, 306. Cambridge, England: Woodhead Publishing Ltd.; 2003. p. 326.

Office for National Statistics. http://www.statistics.gov.uk/hub/index.html. [last visit 02/05/2013]

OIV (International Organisation of Vine and Wine). Statistical report on world viticulture 2013; 2013.

Pasqualino J, Meneses M, Castells F. The carbon footprint and energy consumption of beverage packaging selection and disposal. J Food Eng 2011;103:357-65.

Pattara C, Raggi A, Cichelli A. Life cycle assessment and carbon footprint in the wine supply-chain. Environ Manag 2012a;49(6):1247-58.

Pattara C, Cichelli A, Civitarese C, Di Martino M. A comparison of carbon footprints in wine production: the case of two cooperatives wineries in Central Italy, Le Bulletin de l'OIV, vol. 85, no. 977-978-979. ; 2012b. [juillet-aout-septembre].

Petti L, Raggi A, De Camillis C, Matteucci P, Sára B, Pagliuca G. Life cycle approach in an organic wine-making firm: an Italian case-study. Proceedings Fifth Australian Conference on Life Cycle Assessment, Melbourne, Australia, November 22nd to 24th, 2006; 2006. [Available at: http://www.conference.alcas.asn.au/2006/Petti\%20et\%20al.pdf (last access December 2012)]. 
Petti L, Ardente F, Bosco S, De Camillis C, Masotti P, Pattara C, et al. State of the art of life cycle assessment (LCA) in the wine industry. International conference on life cycle assessment in the agri-food sector. Bari, Italy, September 22-24 2010; 2010.

Pizzigallo ACI, Granai C, Borsa C. The joint use of LCA and emergy evaluation for the analysis of two Italian wine farms. J Environ Manag 2008;86:396-406.

Point E, Tyedmers P, Naugler C. Life cycle environmental impacts of wine production and consumption in Nova Scotia, Canada. J Clean Prod 2012;27:11-20.

Rossini G, Toscano G, Olivi L. Valorizzazione dei cascami della filiera vinicola. Atti del convegno: Attualità della ricerca nel settore delle energie rinnovabili da biomassa. 16-17 Dicembre 2010, Ancona; 2010.

Rugani B, Niccolucci V, Pulselli RM, Tiezzi E. A cradle-to-gate life cycle assessment integrated with emergy evaluation: sustainability analysis of an organic wine production. Proceedings of the SETAC Europe 19th Annual Meeting on Protecting Ecosystem Health: Facing the Challenge of a Globally Changing Environment, May 31st-June 4th, 2009, Göteborg, Sweden; 2009. p. 274.

Rugani B, Vázquez-Rowe I, Benedetto G, Benetto E. A comprehensive review of carbon footprint analysis as an extended environmental indicator in the wine sector. J Clean Prod 2013;54:61-77. [1 September].

Saxe H. LCA-based comparison of the climate footprint of beer vs. wine \& spirits. Institute of Food and Resource Economics, Report no. 207, (on-line, LCA-based comparison of the climate footprint of beer vs. wine \& spirits)978-87-92591-02-9; 2010.

Schlich $\mathrm{EH}$. From vineyard to point of sale: allocation of energy use and $\mathrm{CO}_{2}$-emission to entire supply chains of wine. Proceedings of the 4th Annual Conference, American Association of Wine Economists, June 25-28, 2010, University of California, Davis, California USA; 2010.
Smil V. Phosphorus in the environment: natural flows and human interferences. Annu Rev Energy Environ 2000;25:53-88.

Smith P, Martino D, Cai Z, Gwary D, Janzen H, Kumar P, et al. Agriculture. In climate change 2007: Mitigation. Contribution of Working Group III to the Fourth Assessment Report of the Intergovernmental Panel on Climate Change. In: Metz B, Davidson OR, Bosch PR, Dave R, Meyer LA, editors. Cambridge, United Kingdom and New York, NY, USA: Cambridge University Press; 2007.

Statistical Offices of the Länder. http://www.statistikportal.de/Statistik-Portal/en/. [last visit 02/05/2013].

United States Environmental Protection Agency (USEPA). Emission factor documentation for AP-42, section 9.12.2, wines and brandy, final report; 1995.

Vázquez-Rowe I, Villanueva-Rey P, Moreira MT, Feijoo G. Environmental analysis of Ribeiro wine from a timeline perspective: harvest year matters when reporting environmental impacts. J Environ Manag 2012;98:73-83.

Vázquez-Rowe I, Rugani B, Benetto E. Tapping carbon footprint variations in the European wine sector. J Clean Prod 2013;43:146-55.

Villanueva-Rey P, Vázquez-Rowe I, Moreira MT, Feijoo G. Comparative life cycle assessment in the wine sector: biodynamic vs. conventional viticulture activities in NW Spain. J Clean Prod 2013. http://dx.doi.org/10.1016/j.jclepro.2013.08.026.

Zabalza I, Aranda A, Scarpellini S. Analysis and improvement of energy and environmental costs for small and medium enterprises in the wine sector. Proceedings of the 16th International Conference on Efficiency, Costs, Optimization, Simulation and Environmental Impact of Energy Systems (ECOS 2003), June 30th-July 2nd, 2003, Copenhagen, Denmark; 2003.

Zamagni A, Masoni P, Buttol P, Raggi A, Buonamici R. Finding life cycle assessment research direction with the aid of meta-analysis. J Ind Ecol 2012;16:39-52. 